\title{
PUBLIC PERCEPTION OF SCIENCE OF UNDERGRADUATE STUDENTS FROM THE STATE OF SAO PAULO: A STUDY THROUGH THE PERSPECTIVE OF BIOTECHNOLOGY
}

\author{
PERCEPÇÃO PUBLICA DE CIÊNCIA DE GRADUANDOS DO ESTADO \\ DE SÃO PAULO: UM ESTUDO A PARTIR DA \\ ÓTICA DA BIOTECNOLOGIA
}

\section{PERCEPCIÓN PÚBLICA DE LA CIENCIA DE LOS ESTUDIANTES UNIVERSITARIOS DEL ESTADO DE SAO PAULO: UN ESTUDIO A TRAVÉS DE LA PERSPECTIVA DE LA BIOTECNOLOGÍA}

\author{
Fernanda Oliveira Simon ${ }^{1}$ \\ Estéfano Vizconde Veraszto ${ }^{2}$ \\ José Tarcísio Franco de Camargo \\ Dirceu da Silva ${ }^{4}$ \\ Nonato Assis de Miranda
}

\begin{abstract}
The association between scientific knowledge and attitudes about science has historical, social and fundamental political implications. Therefore, it becomes essential to assess public attitudes in face of science as they relate to the changing context of scientific practices and their implications in practical and social problems. Thus, this article presents the results of a research developed from a mixed approach, which evaluated the public perception of science and the attitudes in face scientific and technological development, from the perspective of biotechnology, in a public composed of students graduate from different localities of the State of São Paulo, Brazil. The results show that science influences directly and positively students' attitudes toward to science.
\end{abstract}

KEYWORDS: Science. Public perception of science. Attitudes towards science and biotechnology.

RESUMO: A associação entre o conhecimento científico e as atitudes frente à ciência possui implicações históricas, sociais e políticas fundamentais. Por isso, torna-se primordial avaliar as atitudes do público frente à ciência, pois elas relacionam-se com a mudança de contexto das práticas científicas e suas implicações nos problemas práticos e sociais. Neste sentido, este artigo apresenta os resultados de uma pesquisa desenvolvida a partir de uma abordagem mista, que avaliou a percepção pública de ciência e as atitudes frente ao desenvolvimento científico e tecnológico, a partir da ótica da biotecnologia, em um público composto por alunos de graduação de diferentes localidades do Estado de São Paulo, no

\footnotetext{
${ }^{1}$ Doutora em Educação pela Universidade Estadual de Campinas. Professora da Faculdade de Santa Lúcia, Mogi Mirim, SP e da Faculdade Comunitária de Campinas - FAC III. Campinas, SP - Brasil. E-mail: fersimon@ uol.com.br.

${ }^{2}$ Doutor em Educação pela Universidade Estadual de Campinas. Professor do Departamento de Ciências da Natureza, Matemática e Educação da Universidade Federal de São Carlos, UFSCAR, São Carlos, SP - Brasil. E-mail: estefanovv@gmail.com.

${ }^{3}$ Doutor em Engenharia Elétrica pela Universidade Estadual de Campinas. Professor do Centro Regional Universitário de Espírito Santo do Pinhal, UNIPINHAL, Espírito Santo do Pinhal, SP - Brasil. E-mail: jtfc@ bol.com.br.

${ }^{4}$ Doutor em Educação pela Universidade de São Paulo. Professor do Departamento de Ensino e Práticas Culturais da Faculdade de Educação - Universidade Estadual de Campinas - UNICAMP, Campinas, SP - Brasil. E-mail: dirceu@unicamp.br.

${ }^{2}$ Doutor em Educação pela Universidade Estadual de Campinas. Professor da Universidade Municipal de São Caetano do Sul - USCS, São Paulo, SP - Brasil - E-mail: mirandanonato@ uol.com.br.

Recebido em: 09/06/2015 Aprovado em: 18/12/2015.
} 
Brasil. Os resultados mostram que, na concepção dos investigados, a ciência influencia direta e positivamente suas atitudes frente à ciência.

PALAVRAS-CHAVE: Ciência. Percepção pública de ciência. Atitudes frente à ciência e biotecnologia.

RESUMEN: La asociación entre el conocimiento y las actitudes hacia la ciencia científica tiene implicaciones históricas, sociales y políticas. Por lo tanto, es esencial evaluar la actitud del público frente la ciencia pues son las actitudes que se relacionan con el contexto cambiante de las prácticas científicas y sus implicaciones sobre los problemas prácticos y sociales. Por lo tanto, este trabajo presenta los resultados de una encuesta desarrollada a partir de un enfoque mixto, que evaluó la percepción pública de la ciencia y las actitudes frente del desarrollo científico y tecnológico, desde la perspectiva de la biotecnología, en un público integrado por estudiantes de graduación de diferentes lugares de Estado de São Paulo, en Brasil. Los resultados obtenidos mediante análisis factorial confirmatorio son indicadores que muestran que las concepciones que tienen las personas acerca de la ciencia influye directa y positivamente sus actitudes hacia la ciencia.

PALABRAS CLAVE: Ciencia. Percepción pública de la ciência. Actitudes frente la ciencia y la tecnológya.

\section{INTRODUCTION}

In an uninterrupted and accelerated way, we see the world is going through continuous changes thanks to a scientific and technological development never seen before in human history. New products and services got the market and change social relations, work processes, ways of communication and exchanges of information and also the way how is done the acquisition of intelligence. In this context, one of the main concerns that appear in studies that attempt to relate science, technology and society is the creation and validation of indicators allow to evaluate the interactions among these three dimensions (VOGT and POLINO, 2003; GARCÍA et al., 2000; VERASZTO et al., 2011, 2013; GUIVANT, 2006).

From this perspective, and considering undergraduate students from São Paulo State as the target public, this paper will show the results of a survey developed to create, analyze and validate a research instrument that, further than, show how individuals understand science, and also be able to show their relationship with the scientific and technological development (VERASZTO et al., 2012).

This study is structured as follows: the first part presents a literature review, focusing on the main concepts of science and biotechnology which also appear in the media and are part of the social imaginary in general that support the hypotheses. The second part presents the methodology and the third, discusses the data analysis and results of the study. The fourth section presents the main conclusions and limitations of the study.

\section{CONCEPTIONS OF SCIENCE}

According to Chauí (2000), it has historically been considered three conceptions of science or scientific ideals as major: the rationalist, whose objectivity is the mathematical model; the empiricist, which takes the objectivity model of Greek medicine and natural history of the seventeenth century; and the constructivist, whose objectivity model comes from the idea of reason as approximate knowledge. 
The rationalist conception which said that science is a deductive and demonstrative rational knowledge such as mathematics, thus able to prove the necessary and universal truth of its statements and results, without leaving any possible doubt. A science is the systematic unity of axioms, postulates and definitions, which determine the nature and properties of its object, and demonstrations that prove the causal relationships governing the investigated object.

The empiricist conception from which science is an interpretation of the facts based on observations and experiments which establish inductions and which, when completed, provide the definition of the object, its properties and its functioning laws. The scientific theory the observations and experiments, so that the experience does not simply have the role of check and confirm concepts, but serves to produce them. That is why, in this conception, there was always great care to establish rigorous experimental methods because of them depended on the formulation of the theory and definition of objectivity investigated.

The constructivist conception - started in the twentieth century - considers science a construction models to describe reality and not a representation of reality itself. The scientist combines two procedures - one coming from rationalism, and others, coming from empiricism - and they added a third, from the idea Approximate correctable and knowledge" (CHAUÍ, 2000, p.321). This concept was proposed by sociologists like David Bloor who considered that there was symmetry between the causes of scientific facts, both considered true, as considered false. He attributes therefore the same social causes for the successes and mistakes thereby questioning the facts and proposing a new way of looking at science; Barry Barnes and Bruno Latour (1977) to whom, scientific facts are collective constructions established through alliances between actors (human and nonhuman) forming a complex network. In this context, by conception of science, we consider the set of beliefs that a person has about it, either from general viewpoints, or about specific topics of scientific work. However, this belief need not be directly linked to the knowledge about the subject. Thus, the knowledge of the process of scientific investigation is important for a student to understand the nature of science and thus might have an effective participation in decision-making about scientific development (CANAVARRO, 2001).

Thus, in the $60 \mathrm{~s}$ and $70 \mathrm{~s}$ there were created several tools to assess the student's attitudes about science. The most commonly used were: the Test of Understanding Science by Cooley and Klopfer (1961), the Nature of Science Scale (NOSS) from Kimball (1965), the Welch Scale (1966), the Scientific Attitude Inventory (SAI) prepared by Moore and Sutman (1970), the predictor scale of Carrera in science of Hill et al.. (1990), the Scientific Attitude Scale (SAS) by Billeh and Zakhariades (1975), the Test of Scientific Attitudes (TOSA) of Kozlow and Nay (1976), the Test of Perception of Scientist and Self (TYPE) by Mackay and White (1976), the Nature Scientific Knowledge Scale (NSKS) of Rubba (1977), the Test of Science-Related Attitudes (TOSRA) developed by Fraser (1978), the Scientific Interest Inventory, the Image of Science and Scientific Scale and Attitudes toward the Science of protocol (WAREING, 1982).

\footnotetext{
${ }^{6}$ These authors are not included in the references because they were not mentioned in this paper as a source of research.
}

\begin{tabular}{l|l|l|l|l|l|l|} 
(C) ETD -Educ. Temat. Digit. & Campinas, SP & v.18 & n.1 & p. 83-103 & jan./abr.2016 & ISSN $1676-2592$
\end{tabular}


Most of the instruments used to measure attitudes about science psychometric are scales as Likert, but some of them are multiple answers, semantic differential or Thustone. However, for most of them, the validity has not been demonstrated because there is not precision in defining the attitude of the object and there is absence of a single, common construct full scale, impeding the analysis of data and interpretation of results (SHRIGLEY; KOBALLA, 1992; AIKENHEAD, 1988; MAS et al., [19-?]).

A common problem is the absence of conceptual definition to measure what it is attitude. In much of the questionnaires, the attitudes are focused only on their cognitive dimension, mingling with science concepts. Thus, attitudes end up being reduced only to beliefs that people have about science, scientists and their work. This causes a problem with the validity of the questionnaire, so there is a mismatch between what you want to measure and what it actually measures (GARDNER, 1996). In addition, there are a lot of differences in the basic concepts of attitudes to science among the authors. In some works the attitude is related to the motivation for the study of science, on the other is related to the values of science, the characteristics of scientists and the scientific method (MAS et al., [19-?]).

According to Cavallo and Laubach (2001), we have six aspects that compose the attitudes that can influence decision making. They are: the concept that one has of himself (own image), happiness in relation to science, absence of anxiety, school science usefulness, student motivation for science and a perception that science is a male activity.

Nowadays, it begins to form a consensus that the University cannot provide a guarantee that the student will remain updated throughout your career. It is for the university to provide elements for self-learning, or "learning to learn" (ENEMARK, 2002). However, the "learning to learn" is not a prerogative of the universities. This should also happen in primary and secondary education, so that people can (and are encouraged to) get more information for decision making.

The usefulness of school science is related to the perception of how it can be applied by the person and society, which has been instrumental in decisions on science, especially among women. They consider the areas belonging to the health (biology, anatomy, medicine, physiology) more useful than the physical sciences (CAVALLO and LAUBACH, 2001).

On the other hand, the student's motivation for science is related to the level of participation in extracurricular activities on the subject. So, the level of interest in matters involving science can have a major impact on the level of participation of the subject in the debates about science. According to Oliver (1990) cited by Cavallo and Laubach (2001) the decline in student motivation is similar to the decline in attitudes to science.

About biotechnology, Horst (2007) identifies three groups of subjects. The first is called consumer group and is focused on the patients' rights. The members of this group believe, for example, that it missing only greater investment to be finding the cure for cancer. 
The second is called behavioral group and it is focuses on the responsibilities of doctors. In this group, the expectation is that the future has key role, that is, if they do not believe in miracles then there should be no cure for cancer.

In the third group (the heroic action), people believe that patients of terminal illnesses should wait for a heroic action (or miracle), since medical science can do no more.

Thus, the hope of improving placed on biotechnology (more specifically in gene therapy) has just trampled on general expectations with respect to future therapies and not on concrete research results (HORST, 2007).

In this way, these expectations function as "productive representations, which tease the conditions of possibility for the development of science and technology" (Horst, 2007).

However, in Brazil, it has been done almost nothing to analyze the attitude of people about the genetics and biotechnology (MASSARANI and MOREIRA, 2005).

To classify and analyze the conceptions of science we base on the work of Gil Perez et al. (2001), but not restrict to him. In this way, we summarize six conceptions of science (Table 1), which are presented below. These conceptions show limited and traditional views about science and scientific research. Nevertheless, they are still part of the social imaginary and have been widely publicized by the media, whether through textbooks or even by the media in general, such as TV, internet, newspaper or magazines with massive circulation.

TABLE 1 - Assertions regarding the conception of science

\begin{tabular}{|c|c|c|}
\hline $\begin{array}{c}\text { Conception of } \\
\text { science }\end{array}$ & Understanding of the concept & References \\
\hline $\begin{array}{l}\text { Empirical-inductive } \\
\text { and atheoretical }\end{array}$ & $\begin{array}{l}\text { It is the vision most commonly found in the literature, where } \\
\text { science is seen as a neutral activity, devoid of evaluative } \\
\text { charges and practical commitments. That is, observation and } \\
\text { experimentation are not influenced by a priori ideas of } \\
\text { scientists. In this conception, science is free of particular } \\
\text { interest both in its conception and in the development of } \\
\text { results. }\end{array}$ & $\begin{array}{l}\text { GIL PÉREZ et al., 2001; } \\
\text { GARCÍA et al., 2000; } \\
\text { GOMES, 2001; } \\
\text { MERTON, 1977; } \\
\text { MacDONALD, } 1996 .\end{array}$ \\
\hline Rigid & $\begin{array}{l}\text { In this conception the scientific method is seen as a set of } \\
\text { steps to be followed mechanically, An algorithm used to } \\
\text { evaluate the acceptability of general propositions, showing } \\
\text { strict control of the scientific process. Science is considered } \\
\text { algorithmic, accurate and infallible, and its development is } \\
\text { regulated by a strict code of rationality. }\end{array}$ & $\begin{array}{l}\text { MacDONALD, 1996; GIL } \\
\text { PÉREZ et al., 2001; } \\
\text { GARCÍA et al., 2000. }\end{array}$ \\
\hline $\begin{array}{l}\text { Unproblematic and } \\
\text { ahistorical }\end{array}$ & $\begin{array}{l}\text { Science is seen as a body of knowledge already prepared and } \\
\text { presented in a ready form, without mentioning the problems } \\
\text { that originated it, its progress and difficulties. It is a concept } \\
\text { widely used in schools, where teaching practice becomes } \\
\text { linked to the frequent use of the textbook and focused on rote } \\
\text { memorization of concepts, assignments, rules and } \\
\text { mathematical formulas. Are left aside the STS relations. }\end{array}$ & $\begin{array}{c}\text { GIL PÉREZ } \text { et al., 2001; } \\
\text { CANAVARRO, 2001; } \\
\text { VILLANI, 2001; } \\
\text { BARROS FILHO, } 1999 .\end{array}$ \\
\hline
\end{tabular}




\begin{tabular}{|c|c|c|}
\hline $\begin{array}{l}\text { Cumulative with } \\
\text { linear growth of } \\
\text { cientific knowledge }\end{array}$ & $\begin{array}{c}\text { Science is seen as a progressive and cumulative process of } \\
\text { approaching the truth, inexorably leading and without } \\
\text { comparable alternative developments, complementing the } \\
\text { vision rigid. }\end{array}$ & $\begin{array}{l}\text { GOMES, 2001; GARCÍA } \\
\text { et al., 2000; LEDERMAN } \\
\text { \& O'MALLEY, 1990; } \\
\text { AIKENHEAD, 1988; GIL } \\
\text { PÉREZ et al., 2001. } \\
\end{array}$ \\
\hline $\begin{array}{l}\text { Elitist and } \\
\text { individualistic of } \\
\text { Science } \\
\text { (autonomous) }\end{array}$ & $\begin{array}{l}\text { Science is seen as endowed with internal logic. Scientific } \\
\text { knowledge is seen as the work of isolated geniuses, totally } \\
\text { disinterested and without goals, being that only experts have } \\
\text { the ability to determine the direction of their advance and no } \\
\text { external aspect may influence the development of science. } \\
\text { The scientific work is considered a reserved area for a } \\
\text { specially gifted minority and incomprehensible to the lay } \\
\text { public. It is an elitist conception fairly treated in the literature. }\end{array}$ & $\begin{array}{l}\text { GIL PÉREZ et al., 2001; } \\
\text { GOMES, 2001; GARCÍA } \\
\text { et al., 2000. }\end{array}$ \\
\hline Universalist & $\begin{array}{c}\text { In this conception the results of science are valid regardless of } \\
\text { the cultural, political, social or economic context that } \\
\text { generated or will apply it. It is said that the judgment of the } \\
\text { relevance, usefulness or results of a work is given in an } \\
\text { impersonal and impartial way. }\end{array}$ & $\begin{array}{l}\text { GOMES, 2001; } \\
\text { MERTON, } 1979 .\end{array}$ \\
\hline
\end{tabular}

Fonte: Source: Simon, 2009

\section{CONCEPTIONS OF SCIENCE FROM THE BIOTECHNOLOGY}

Different conceptions of science are accepted by society and disseminated by media and literature from incomplete, simplified and often erroneous perspectives in certain aspects. Contributing to a scenario that hardly shows the real role of scientific work, many times the dissemination of science made by popular media prioritize a focus of scientific and technological development based on themes, as biotechnology, global warming, the neurosciences, among others (SIMON, 2009). Issues such as cloning, genetically modified foods, pharmaceutical license and its social consequences and moral acceptability are affected by individuals and affect society broadly (LIAKOPOULOS, 2002).

The most common themes in the research instruments about public perception of science are: genetic engineering, agricultural biotechnology, nuclear energy and the environment. Therefore we chose to use as a mediator theme for the development of part of the research instrument biotechnology, more specifically the area of genetic engineering, for being a controversial subject and being widely used in instruments about public perception around the world as a key concept for understanding relationship between public and science. This way, the opinions of people about biotechnology cam reflect attitudes about the role of science and scientific risk (ALLUM et al., 2008; BESLEY \& SHANAHAN, 2005; DAHINDEN, 2002).

\section{METHODOLOGY}

Considering the points discussed before, in this topic, we will discuss the theoretical frameworks and the ways of measuring the conceptions of science, presenting the methodological guidelines that will guide the design and analysis of the research. As noted previously, we chose a mixed approach, considering two distinct phases of the research: the preparation of the survey 
instrument and the analysis of the results.

\section{First stage: Development of the research instrument}

The first stage of the research uses the technique of the qualitative approach to support the instrument. Methods of exploratory research were performed (literature review) whit the purpose of gathering the composition of the Likert instrument. Thus, the theoretical framework was explored, classified, organized and interpreted according to Content Analysis technics (BARDIN, 2006; PATTON, 1980; MINAYO, 2001). Starting from the organized data, they were categorized and sorted materially, as presented in the tables 1,2 and 3. These results served as the basis for the creation of the assertive of the Likert instrument as we shall see in sequence.

All conceptions of science presented in this study, in a greater or lesser degree, are part of the social imaginary and eventually preventing a public participation in decisions involving science and their technological implications. Besides, there is a significant lack of understanding about the aspects of the scientific processes in the media and also in national and international official documents (VERASZTO et al., 2013; TYTLER \& DUGGAN, 2001; KERR et al., 2007; DAAMEN et al., 1990).

For the composition of the statements referring to the concepts about science we used two approaches:

i. The first focused on a conception of science more generally based on the concepts presented earlier from the literature review (Table 1)

ii. The second using biotechnology as mediator theme. In this moment, we seek to reveal attitudes of the students in face of the scientific development since these can also reflect their conceptions about science, as presented previously (ALLUM et al., 2008; BESLEY \& SHANAHAN, 2005).

So, for each one of the six conceptions presented it was elaborated an assertion (Table 2) to synthetize it.

TABLE 2 - Assertions regarding the conception of science

\begin{tabular}{c|c|c}
\hline Conception of science & Assertion & References \\
\hline $\begin{array}{c}\text { empirical-inductive and } \\
\text { atheoretical }\end{array}$ & $\begin{array}{c}\text { Scientists discover new theories } \\
\text { watching reality. }\end{array}$ & $\begin{array}{c}\text { GIL PÉREZ } \text { et al., 2001; GARCÍA } \text { et } \\
\text { al., 2000; GOMES, 2001; MERTON, } \\
\text { 1977; MacDONALD, 1996. }\end{array}$ \\
\hline Rigid & $\begin{array}{c}\text { Scientists are extremely strict in the } \\
\text { use of scientific method. }\end{array}$ & $\begin{array}{c}\text { MacDONALD, 1996; GIL PEREZ } \text { et } \\
\text { al., 2001; GARCÍA } \text { et al., 2000. }\end{array}$ \\
\hline $\begin{array}{c}\text { The science learned in school is } \\
\text { related to the everyday life. }\end{array}$ & $\begin{array}{c}\text { GIL PÉREZ } \text { et al., 2001; } \\
\text { CANAVARRO, 2001; VILLANI, } \\
\text { 2001; BARROS FILHO, 1999. }\end{array}$ \\
\hline $\begin{array}{c}\text { Cumulative with linear growth } \\
\text { of scientific knowledge }\end{array}$ & $\begin{array}{c}\text { The new scientific theories } \\
\text { complement old theories. }\end{array}$ & $\begin{array}{c}\text { GOMES, 2001; GARCÍA } \text { et al., 2000; } \\
\text { LEDERMAN \& O'MALLEY, 1990; } \\
\text { AIKENHEAD, 1988; GIL PÉREZ et } \\
\text { al., 2001. }\end{array}$ \\
\hline $\begin{array}{c}\text { elitist and individualistic of } \\
\text { science (autonomous) }\end{array}$ & $\begin{array}{c}\text { Only scientists have authority to } \\
\text { decide what should be researched. }\end{array}$ & $\begin{array}{c}\text { GIL PÉREZ } \text { et al., 2001; GOMES, } \\
\text { 2001; GARCÍA } \text { et al., 2000. }\end{array}$ \\
\hline
\end{tabular}

\begin{tabular}{l|l|l|l|l|l|l} 
(C) ETD - Educ. Temat. Digit. & Campinas, SP & v.18 & n.1 & p. 83-103 & jan./abr.2016 & ISSN 1676-2592
\end{tabular}



applied to any human being.

Fonte: Source: Simon, 2009

Besides the six assertions presented in Table 1, using biotechnology as a mediator theme, we also developed three more assertions related to beliefs in genetic engineering and six assertions regarding to the knowledge in the area. The assertions with its respective references are presented in Table 3.

Thus, the measurement model was composed of six assertions related with the conceptions of science and other nine assertions related with the attitudes in face of the scientific development.

TABLE 3 - Assertions related to biotechnology and genetic engineering

\begin{tabular}{|c|c|c|}
\hline $\begin{array}{c}\text { Attitudes in face of } \\
\text { science }\end{array}$ & Assertion & References \\
\hline \multirow[t]{3}{*}{ Genetic engineering } & Homosexuality is a genetic trait. & \multirow{3}{*}{$\begin{array}{c}\text { Eurobarômetro apud } \\
\text { GODIN e GINGRAS, } \\
2000 .\end{array}$} \\
\hline & The tendency to crime is of genetic origin. & \\
\hline & $\begin{array}{l}\text { The benefits of genetic engineering outweigh its negative } \\
\text { effects. }\end{array}$ & \\
\hline \multirow[t]{6}{*}{$\begin{array}{l}\text { Knowledge in } \\
\text { biotechnology }\end{array}$} & $\begin{array}{c}\text { In the early months of pregnancy it is already possible to } \\
\text { know if the child has or not some genetic disease. }\end{array}$ & \multirow[t]{6}{*}{ SIMON, 2009.} \\
\hline & $\begin{array}{c}\text { More than half of human genes are identical to those of } \\
\text { chimpanzees. }\end{array}$ & \\
\hline & The cloning of living things produces identical beings. & \\
\hline & It's impossible to insert animal genes in plants. & \\
\hline & It is possible to transplant only a piece of liver. & \\
\hline & It is possible to create an organ from stem cells. & \\
\hline
\end{tabular}

Fonte: Source: Simon, 2009

\section{Second stage: quantitative aspects}

Based on the statements presented, we performed a confirmatory factor analysis to see if the indicators created really compose the assumed construct (conceptions of science and attitudes in face of science), and if there is an indication for the formation of new constructs or the reduction of indicators. The goal of the confirmatory factor analysis is check which set of assertions really measure the proposal presented (HAIR et al., 2005; SELLTIZ et al., 1987).

The final constitution of the survey instrument developed was made by the scale built by Rensis Likert in 1932, composed by a set of assertions in which the answers are asked to point one in five options of answer: strongly disagree, disagree, neither agree nor disagree, agree and strongly agree. To treat them quantitatively, it is given a score ranging from 1 to 5. More specifically, this rating was done as follows: $1=$ strongly disagree, $2=$ disagree, $3=$ neither agree nor disagree (don't know), $4=$ agree e $5=$ strongly agree. The choice of this structured questionnaire is due to the fact that it has less time to be completed. We also prioritize the anonymity of responses to avoid distortions of the researchers (SELLTIZ et al., 1987). 
The validation of the instrument must be done in two ways: theoretical validation and semantic validation (PASQUALI, 2003). Considering these two points, we undertake the two validations:

i. The theoretical validation of the assertions of the Likert scale and questions was made by seven specialists (an educator, two physicists, two engineers, a psychologist and an adman). To all it was asked to analyze the instrument in order to verify the adequacy of the assertions to the proposed theme.

ii. The semantic validation of the assertions and questions was made by seventeen undergraduate students invited to answer the survey. After answering, it was made an interview with each one of them in order to verify what they understand about each assertion and search for suggestions for improving the instrument. In addition, it was also marked the time required to complete the questionnaire.

\section{Characteristics of the sample}

Our sample consisted of undergraduate students from different courses, from the exact, biological and human areas, regardless of the year of admission. The chosen sample was nonprobabilistic, since the probability that an individual belonging to the sample was not known (MALHOTRA, 2001).

Crowley e Fan (1997) point that, although there is no general agreement about the sample size, the amount of two hundred has been suggested in similar studies. The same statement is made by Hair et al. (2005) by stating that, even without a correct sample size, it is recommended the adoption of a number between one hundred and two hundred observations.

Considering these aspects, our sample consisted, at first, of 1658 students of undergraduate courses in different cities of Sao Paulo State, such as Mogi-Guaçu, Mogi-Mirim, Campinas, Indaiatuba, Itú, Santa Bárbara d'Oeste, Sao Paulo and Sao Carlos, of which $20.4 \%$ are from public colleges and 79,6\% are from private colleges (in Brazil, the largest enrollment in colleges lies with the private institutions. For this reason, the most of our sample was obtained in private universities).

In addition, 43,3\% (718) of respondents were male, 56,6\% (939) were female and one subject did not answered this question. The average age was 25 years with standard deviation of 6.4 years. The subjects studied are spread over 44 undergraduate courses (Table 4). Data were collected during classes.

However, only 970 questionnaires were considered in the Confirmatory Factor Analysis because the others were not fully filled. On the other hand, this reduction in the number of respondents did not harm statistically the research results. 
TABLE 4 - Undergraduate courses

\begin{tabular}{l|c|c}
\hline Course & Frequency & Percentage \\
\hline Pedagogy & 314 & 18,9 \\
\hline Administration & 287 & 17,3 \\
\hline Nursing & 119 & 7,2 \\
\hline Production Engineering & 106 & 6,4 \\
\hline Computer Science & 93 & 5,6 \\
\hline Technologist in Logistics & 79 & 4,8 \\
\hline Administration - Foreign Trade & 79 & 4,8 \\
\hline Mechanical engineering & 54 & 3,3 \\
\hline Technologist in Human Resource Management & 44 & 2,7 \\
\hline Business management & 41 & 2,5 \\
\hline Environmental engineering & 41 & 2,5 \\
\hline Environmental management & 36 & 2,2 \\
\hline Accounting & 35 & 2,1 \\
\hline Information Systems & 34 & 2,1 \\
\hline Chemical engineering & 32 & 1,9 \\
\hline Control and automation engineering & 31 & 1,9 \\
\hline Not answered & 31 & 1,9 \\
\hline Nutrition & 30 & 1,8 \\
\hline Technology in analysis and systems development & 29 & 1,7 \\
\hline Physical education & 27 & 1,6 \\
\hline Psychology & 25 & 1,5 \\
\hline Electrical engineering & 16 & 1 \\
\hline Leisure and Tourism & 11 & 0,7 \\
\hline Obstetrics & 10 & 0,6 \\
\hline Others & 54 & 3,2 \\
\hline
\end{tabular}

Fonte: Source: Simon, 2009

The courses with bigger representation in our sample were pedagogy $(18,9 \%)$, administration (17.3\%), nursing (7.2\%) and production engineering (6,4\%). Classified as others, we have courses with low statistical significance. They are Biological Sciences, Engineering (unspecified), Gerontology, Physics, Dance, Literature, Geography, Mathematics, Industrial Engineering, Marketing, Information Technology (IT), Mechatronics Engineering, Visual Arts, Food Engineering, Philosophy, Degree in Chemistry, BS in Chemistry, History, Social Sciences, Public Policy Management and Bachelor of Science.

\section{DATA ANALYSIS}

\section{Model validation}

The validation will be analyzed by observing four characteristics: one-dimensionality of the constructs, each reliability, convergent validity and the global model fit.

The Unidimensionality of the constructs consists in verify if the established indicators actually represent a single construct, which is a premise to construct reliability (Hair et al., 2005), thus, each indicator must be strongly associated with a single latent variable (construct). For this, we 
will observe that each value of the normalized residuals matrix of each construct is small (less than 2.58, a 5\% significance level), which would indicate that the effects of these wastes on the overall fit of the model is low.

The reliability of each construct is a measure of the internal consistency of its indicators and shows the adequacy of scales to measure it. For evaluating the reliability adopt the Cronbach's alpha. According to Hair et al. (2005), an alpha value above 0.6 is indicative of the appropriateness of indicators to measure the construct.

The validity checks whether the instrument measures what it is intended to do. One of validity forms is converged that verifies the extent to which the indicators are able of measuring a latent variable (construct). Its findings will be made in compliance with the standardized factor loadings. Will be deemed accepted as large and significant those that present significance in t-test below 0.05 (PASQUALI, 2003).

To check the fit of the overall model, we will use two types of measures: the absolute adjustment measures, which compare the input matrix with that predicted by the proposed model and the incremental adjustment measures, which compare the proposed model with a null model.

Among the absolute adjustment measures, we used chi-square weighted $\left(\mathrm{x}^{2} /\right.$ degrees of freedom), Goodness-of-fit (GFI) and Root Mean Square Error of Approximation (RMSEA). However, it is important to mention that the chi-square weighted is a good model adjustment indicator only for samples with size between 100 and 200 observations and problematic when the extent that the number of sample elements move away from this range. For this reason, other indices should be considered in the analysis. The criterion that the present study will adopt to be accept, in case of measure will be values below three. The Goodness-of-fit (GFI) compares the waste from data arrays observed and estimated, producing an indicator that ranges from zero (poor fit) to one (perfect fit). It will be deemed accepted value that is equal or greater than 0.9. For the Root Mean Square Error of Approximation (RMSEA) will be deemed accepted if it is below 0.08, since this measure seeks to correct the chi-square tendency to reject a specified model based on a relatively large sample (HAIR et al., 2005).

Among the incremental adjustment measures, we will use Normed fit index (NFI), TuckerLewis Index (TLI), Adjusted Goodness-of-Fit Index (AGFI) and Comparative fit index (CFI). For all these measures, we will accept only values equal or greater than 0.9 (HAIR et al., 2005). The NFI is the most widely used measure of adjustment, providing a comparison between the values of chisquare proposed model and the value of chi-square null model. The Tucker-Lewis Index, also known as nonnormed fit index (NNFI), ponders the degrees of freedom and is considered a fairly robust rate, combining parsimony as a comparative index between the proposed and null models.

The Adjusted Goodness-of-Fit Index is an extension of GFI adjusted by the ratio of degrees of freedom of the model and the degrees of freedom of the Null model, while Comparative fit Index is the more appropriate measure in the development of strategies and comparison models (GOSLING and GONÇALVES, 2003). 
According to Hair et al. (2005), based on the evaluation of the adjustment indices, the researcher must consider potential changes in the theoretical model being tested by conducting its review until they reach a good adjustment of the constructs.

Nevertheless, the authors add that the estimation of the above adjustment ratios will be possible only if the constructs in question are acceptable levels of measurement. Among the main problems there is the existence of variances non-significant or negative the error variables which make it impossible to run the program, coefficients exceeding the value 1 and or very high error values, which denotes low explanatory power of the indicator variable.

Another item suggested in the literature about the use of confirmatory factor analysis is the data normality assumption like the Kolmogov-Smirnov test to assess adherence to the normal distribution of each of the assertions of the survey instrument.

It is important to mention that because the scope of this article it was not possible to present these adjustment measures. However, they were considered to carry out the partial data analysis whose results are presented herein.

\section{Confirmatory Factor Analysis}

In this stage of the research we selected only the participants that answered all questions. This way, the analysis included 970 respondents. All parameters were estimated based on the Unweighted Least Squares Method (ULS). Table 5 shows the variables (assertions) remaining in the model in each of the constructs, the $t$ values and their significance.

TABLE 5 - Measurement model

\begin{tabular}{|c|c|c|c|c|}
\hline Construct & Variable (assertions or indicators) & factorial load & $\mathbf{t}$ & Sig \\
\hline \multirow[t]{12}{*}{ Conception of science } & $\begin{array}{l}\text { The benefits of genetic engineering outweigh its negative } \\
\text { effects. }\end{array}$ & 0,545 & 26,348 & 0,0207 \\
\hline & Is possible to create an organ from stem cells. & 0,434 & 21,753 & 0,0200 \\
\hline & $\begin{array}{c}\text { The results of genetic research can be applied to any human } \\
\text { being. }\end{array}$ & 0,425 & 21,345 & 0,0199 \\
\hline & It is possible to transplant only a piece of liver. & 0,375 & 19,131 & 0,0196 \\
\hline & $\begin{array}{c}\text { More than half of human genes are identical to those of } \\
\text { chimpanzees. }\end{array}$ & 0,335 & 16,942 & 0,0198 \\
\hline & $\begin{array}{c}\text { In the early months of pregnancy it is already possible to } \\
\text { know if a child has or not any genetic disease. }\end{array}$ & 0,333 & 17,197 & 0,0194 \\
\hline & Scientists discover new theories watching reality. & 0,328 & 16,036 & 0,0204 \\
\hline & The cloning of living things produces identical beings. & 0,282 & 14,269 & 0,0197 \\
\hline & The science learned in school is related to the everyday life. & 0,258 & 13,008 & 0,0199 \\
\hline & The new scientific theories complement old theories. & 0,247 & 12,282 & 0,0201 \\
\hline & Scientists are extremely strict in the use of scientific method. & 0,226 & 11,473 & 0,0197 \\
\hline & Homosexuality is a genetic trait. & 0,192 & 10,153 & 0,0189 \\
\hline \multirow[t]{5}{*}{ Attitude } & $\begin{array}{l}\text { Introducing human genes into a bacterium to produce } \\
\text { vaccines or drugs (e.g. insulin for diabetics). }\end{array}$ & 0,551 & 26,827 & 0,0205 \\
\hline & Donate my blood (or genetic material) for scientific research. & 0,509 & 24,915 & 0,0204 \\
\hline & $\begin{array}{l}\text { Would use genetic tests to detect diseases such as cancer or } \\
\text { neurological diseases before they appear. }\end{array}$ & 0,505 & 23,885 & 0,0211 \\
\hline & $\begin{array}{l}\text { You should allow the creation of embryos for the } \\
\text { development of stem cells. }\end{array}$ & 0,466 & 20,750 & 0,0225 \\
\hline & Using genetic manipulation of embryos at the request of the & 0,449 & 20,676 & 0,0217 \\
\hline
\end{tabular}




\begin{tabular}{|c|c|c|c|}
\hline $\begin{array}{l}\text { parents so that their children do not develop genetic } \\
\text { disorders. }\end{array}$ & & & \\
\hline $\begin{array}{l}\text { Develop genetically modified animals for purposes of } \\
\text { scientific research in the medical field. }\end{array}$ & 0,448 & 19,959 & 0,0225 \\
\hline $\begin{array}{c}\text { Introducing human genes into animals to produce human } \\
\text { organs for transplantation. }\end{array}$ & 0,444 & 19,423 & 0,0229 \\
\hline
\end{tabular}

Fonte: Source: Simon, 2009

The significance of $t$ values test presented in Table 2 are shown below 0,05 for all evaluated indicators. This indicates a good convergent validity, so, the indicators are capable of measuring each of the constructs (HAIR et al., 2005).

In the construct "conception", the assertions "the tendency to crime is of genetic origin", "only scientists have the power to decide what should be investigated" and "it is impossible to insert animal genes into plants" were excluded from the final model. Among the individuals surveyed, $67.7 \%$ disagree that crime is genetic in origin, and those who are coursing production engineering are the ones who most disagree with this assertion. Regarding to the assertion "only scientists have the power to decide what should be researched", 65,2\% disagree and student from business administration are the one the least disagree. Besides, $64.2 \%$ of subjects responded "do not know" to the assertion "it is impossible to insert animal genes in plants".

In the construct attitudes in face of science, the assertions "allow companies to use genetic evaluation for selection of employees" and "use genetic manipulation of embryos at the request of parents for their children to have certain physical characteristics such as eye color" were excluded from the attitudes construct. This is explained by the fact that $84.3 \%$ of the subjects studied disagreed that we should allow companies to use genetic evaluation for selection of employees. In relation to "use the genetic manipulation of embryos at the request of parents for their children to have certain physical characteristics such as eye color" $67 \%$ of the subjects disagreed.

\section{Frequency analysis}

Table 6 shows the responses of the subjects in relation to the assertions of the research instrument.

TABLE 6 - Frequency and percentage of responses for each statement

\begin{tabular}{|c|c|c|c|c|}
\hline Construct & Variable (assertions or indicators) & factorial load & $\mathbf{t}$ & Sig \\
\hline \multirow[t]{10}{*}{ Conception of science } & $\begin{array}{l}\text { The benefits of genetic engineering outweigh its negative } \\
\text { effects. }\end{array}$ & 0,545 & 26,348 & 0,0207 \\
\hline & It is possible to create an organ from stem cells. & 0,434 & 21,753 & 0,0200 \\
\hline & $\begin{array}{l}\text { The results of genetic research can be applied to any human } \\
\text { being. }\end{array}$ & 0,425 & 21,345 & 0,0199 \\
\hline & It is possible to transplant only a piece of liver. & 0,375 & 19,131 & 0,0196 \\
\hline & $\begin{array}{l}\text { More than half of human genes are identical to those of } \\
\text { chimpanzees. }\end{array}$ & 0,335 & 16,942 & 0,0198 \\
\hline & $\begin{array}{l}\text { In the early months of pregnancy it is already possible to } \\
\text { know if a child has or not any genetic disease. }\end{array}$ & 0,333 & 17,197 & 0,0194 \\
\hline & Scientists discover new theories watching reality. & 0,328 & 16,036 & 0,0204 \\
\hline & The cloning of living things produces identical beings. & 0,282 & 14,269 & 0,0197 \\
\hline & The science learned in school is related to the everyday life. & 0,258 & 13,008 & 0,0199 \\
\hline & The new scientific theories complement old theories. & 0,247 & 12,282 & 0,0201 \\
\hline
\end{tabular}




\begin{tabular}{c|c|c|c|c}
\hline & Scientists are extremely strict in the use of scientific method. & 0,226 & 11,473 & 0,0197 \\
\cline { 2 - 5 } & Homosexuality is a genetic trait. & 0,192 & 10,153 & 0,0189 \\
\hline \multirow{2}{*}{ Attitude } & $\begin{array}{c}\text { Introducing human genes into a bacterium to produce } \\
\text { vaccines or drugs (e.g. insulin for diabetics). }\end{array}$ & 0,551 & 26,827 & 0,0205 \\
& Donate my blood or genetic material) for scientific \\
& research. & 0,509 & 24,915 & 0,0204 \\
\hline & $\begin{array}{c}\text { Would use genetic tests to detect diseases such as cancer or } \\
\text { neurological diseases before they appear. }\end{array}$ & 0,505 & 23,885 & 0,0211 \\
\hline & $\begin{array}{c}\text { You should allow the creation of embryos for the } \\
\text { development of stem cells. }\end{array}$ & 0,466 & 20,750 & 0,0225 \\
\hline & $\begin{array}{c}\text { Using genetic manipulation of embryos at the request of the } \\
\text { parents so that their children do not develop genetic } \\
\text { disorders. }\end{array}$ & 0,449 & 20,676 & 0,0217 \\
\hline & $\begin{array}{c}\text { Develop genetically modified animals for purposes of } \\
\text { scientific research in the medical field. }\end{array}$ & 0,448 & 19,959 & 0,0225 \\
\hline & $\begin{array}{c}\text { Introducing human genes into animals to produce human } \\
\text { organs for transplantation. }\end{array}$ & 0,444 & 19,423 & 0,0229 \\
\hline
\end{tabular}

Fonte: Source: Simon, 2009

Based on the analysis of Table 3 we find that $64.1 \%$ students agree that scientists discover new theories watching reality, 53.8\% say that science learned in school is related to the everyday life, while $65.2 \%$ disagree that only scientists have the power to decide what should be researched. In relation to these responses, we found a traditional positioning present in the opinion of the majority of undergraduates from the State of São Paulo. Thus the position of Slee (1964); Simpson and Wasik (1978); Wilson (1983); Soyibo (1985) that positive attitude to science subjects improve science achievement is further challenged. So, 'it is therefore not necessary for teachers to dissipate his/ her time to make the students develop scientific attitude or attitude to science in attempt to improve science achievement of the students' (OLASEHINDE and OLATOYE, 2014, p.450).

Considering the six questions related to scientific knowledge related to the mediator theme of biotechnology, we found that, in five of them, most of the answers are placed in the category "do not know". They are: it is impossible to insert animal genes in plants $(64,1 \%)$, more than half of human genes are identical to those of chimpanzees $(50,7 \%)$, it is possible to transplant only a piece of liver $(46,1 \%)$, it is possible to create an organ from stem cells $(40,7 \%)$ and cloning of living things produces identical beings $(38,2 \%)$. In addition, $47.1 \%$ were unable to assess whether the benefits of genetic engineering outweigh its negative effects, $41 \%$ could not tell if the scientists are extremely strict in the use of scientific method, $40 \%$ if new scientific theories complement the old theories and $37.8 \%$ could not opine whether the results of genetic research can be applied to any human being.

In a certain way, these results show little knowledge of the Brazilian public, in this case, college students, about biotechnology, as previous research have pointed (KAMALDEEN \& POWELL, 2000). They found, for example, that only $37 \%$ of the Brazilian public were aware of genetically modified food issues, compared to ratings of $66-95 \%$ in other developed countries. "Even though issues of biotechnology have now confronted selected developing world countries such as Brazil or Zambia, we can assume that awareness and knowledge rates are lower overall in these countries, but that they are on the increase in the cities" (BROSSARD \& SHANAHAN, 2007, p.8). 
In relation to attitudes in face of science, we found that $81.2 \%$ of the students would use genetic tests to detect diseases such as cancer or neurological diseases before they appear, while $63,6 \%$ said that in the early months of pregnancy it is already possible to know if a child has or not any genetic disease. Furthermore, $67.8 \%$ agree with the introduction of human genes into a bacterium to produce medicines or vaccines, $59.5 \%$ would donate their blood or genetic material for scientific research and $53.6 \%$ say that it should be allowed to create embryos for the development of stem cells. On the other hand, $47.4 \%$ of them agree to use genetic manipulation of embryos at the request of the parents, so that, their children do not develop genetic disorders, while $17.3 \%$ agree to use it to choose the physical characteristics.

We also found that $51.5 \%$ of the students did not agree to develop genetically modified animals for purposes of scientific research in the medical field and $48.1 \%$ disagreed with the introduction of human genes into animals to produce human organs for transplantation. They also consider that neither homosexuality $(56.7 \%)$, nor the tendency to crime $(67.7 \%)$ is genetic characteristics.

These results show that the attitudes of students about science can be related to science teaching in elementary school or in college, after all, many factors could contribute to student's attitude towards studying science (ADESOJI, 2008). For example, Slee (1964) indicated that students' attitude and interests could play substantial role among pupils studying science. Several studies (including Simpson, 1978, Wilson, 1983, Soyibo, 1985) report that students' positive attitudes to science correlate highly with their science achievement (ADESOJI, 2008).

Finally, it is important to say that men can think differently from women like students from different courses can do. So, to compare the responses of men with women and from students in different courses, we use the test Mann-Whitney (suitable for the comparison of two samples) which presented significance value less than 0.05 in some assertions, indicating that the views of men and women are different.

For example, we find out that, women tend to disagree in relation to the introduction of human genes in animals to produce human transplant organs and for the development of animal genetically modified for scientific research purposes in the medical field. They also tend to disagree that the results of genetic research can be applied to any human being, while men are indifferent. On the other hand, more than half of women tend to agree that scientists discover new theories observing reality and that in the first months of pregnancy have known whether or not the child has any genetic disease. Comparing with women, men tend to agree more with the use of tests to detect genetic diseases before they appear, of introducing genes human a bacterium to produce medicines and the creation of embryos for the development of stem cells.

To compare students' opinion from different courses the results show that, the engineering students agree with the introduction of human genes in animals to produce human organs for transplant (84\%), while other groups tend to disagree. They also agree that the benefits of genetic 
engineering are greater than its negative effects $(57 \%)$, while the other groups seem to have no formed opinion.

Nursing students $(31.9 \%)$ and pedagogy $(27.7 \%)$ are the courses that most disagree with the creation of embryos for the development of stem cells and the business administration and pedagogy courses most disagree that results of genetic research can be applied to any human being (38.6\% and $40.8 \%$, respectively) in comparison with the other courses. These results are similar to research done by Fisher et. al. (2005) that indicate a diversity of beliefs and attitudes towards genetic modification amongst those within the science community, and highlight the importance of understanding ethics and myths in dealing with them.

On the other hand, those who are studying Pedagogy are the least likely to agree to the use of genetic manipulation of embryos to the request of parents so that their children do not develop genetic diseases. It also observed that educators and engineers are the ones who agree that new scientific theories complement the old theories.

\section{FINAL CONSIDERATIONS}

In this study, our goal was to determine with statistical reliability, if there is any causal relationship or dependence between the conceptions that people have about science and their attitudes to it, mediated by some social indicators.

In general, the study revealed that undergraduate students of the State of São Paulo have a traditional view of scientific work. The viewpoint that became more applicant was the empiricist. This approach shows that the majority of respondents agree with the idea that science is done from observation of nature. The students surveyed also showed favorable opinions about the idea that science learned in school is directly related to daily life, but disagree that only scientists have the capacity to produce knowledge. On the other hand, they have, in general, favorable attitudes toward science by agreeing to use several advances from biotechnology.

It worth to say that, considering that the purpose of this paper was to present the procedures used to prepare and validate a research instrument aimed at raising the public awareness about science, the objectives were reached. The validated instrument may be valuable in data collection to identify the perceptions of college students about biotechnology, with emphasis on genetic engineering in future research, complementing the results established here preliminarily.

Despite the controversies in the answers, the conception of science and the attitudes that individuals have in relation to the same can also be reflections of individual and fundamental political disagreements about the role of science in society, not reflecting in this way, simple deficits in understanding and communication of science. Thus, indicating the role that the media in science communication should be evaluated in light of current discussions on science and society (PITRELLI et al., 2006). 
In addition, we know that efforts to increase understanding of genetic engineering, in order to empower people to make better informed decisions, may have the unintended effect to change attitudes in a more positive direction, since that, historically, it is assumed that the greater the knowledge in a certain area, greater will be its acceptance (SANDERSON, 2005). In this way, this research instrument, now validated, enables this type of analysis.

\section{REFERENCES}

ADESOJI, F. A. Managing Students' Attitude towards Science through Problem: Solving Instructional Strategy. Anthropologist, v. 10, n. 1, p. 21-24. 2008. Disponível em: < http://goo.gl/HfNj9E >. Acesso em: 09 jun. 2015. ISSN 1548-1433.

AIKENHEAD, Glen S. An analysis of four ways of assessing student beliefs about STS topics. Journal of Research in Science Teaching, v. 25, p. 607-627. 1988. Disponível em: < http://goo.gl/PGrPej>. Acesso em: 09 jun. 2015. ISSN 1098-2736.

ALLUM, Nick; STURGIS, Patrick; TABOURAZI, Dimitra; BRUNTON-SMITH, Ian. Science knowledge and attitudes across cultures: a meta-analysis. Public Understanding of Science, v. 17, n.1, p. 35-54. 2008. Disponível em: < http://goo.gl/hnCR7G>. Acesso em: 09 jun. 2015. ISSN 1361-6609.

BARDIN, Laurence. Análise de conteúdo. Lisboa: Edições 70, 2006.

BARROS FILHO, Jomar. Construção de um sistema de avaliação contínuo em um curso de eletrodinâmica de nível médio. Dissertação (Mestrado em Educação) - Faculdade de Educação, Universidade Estadual de Campinas, Campinas, SP, 1999. Disponível em: < http://goo.gl/A25IZQ>. Acesso em: 09 jun. 2015.

BARNES, B. Interests and the growth of knowledge. London: Routledge \& Kegan Paul, 1977.

BESLEY, John. C.; SHANAHAN, James. Media attention and exposure in relation to support for agricultural biotechnology. Science Communication, v. 26, n. 4, p. 347-367. 2005. Disponível em: < http://goo.gl/BC4ywv>. Acesso em 09 jun. 2015. ISSN 1552-8545.

BROSSARD, Dominique; SHANAHAN James. Perspectives on communication about agricultural biotechnology. In: BROSSARD, Dominique; SHANAHAN, James; NESBITT, T. Clint. (Eds.) The public, the media, and agricultural biotechnology: an international casebook. Cambridge, MA: Oxford, 2007, p. 3-20. Disponível em: 〈 http://goo.gl/FBJDXT>. Acesso em: 09 jun. 2015.

CANAVARRO, José Manuel. O que se pensa sobre a ciência. Coimbra: Quarteto Editora, 2001.

CAVAllO, Ann. M. L.; LAUBACH, Timothy. A. Student's perceptions and enrollment decisions in differing learning cycle classroom. Journal of Research in Science Teaching, v. 38, n. 9, p. 1029-1062. 2001. Disponível em: <http://goo.gl/7K1nRP>. Acesso em: 09 jun. 2015. ISSN: 1098-2736.

CHAUÍ, Marilena. Convite à Filosofia. 7. ed. São Paulo: Ática, 2000.

CROWLEY, S. L.; FAN, X. Structural equation modeling: basic concepts and applications in personality assessment research. Journal of Personality Assessment, v. 3, n. 68, p.508-531. 1997. Disponível em: < http://goo.gl/o2YZsJ >. Acesso em: 09 jun. 2015. ISSN: 1532-7752. 
DAAMEN, Dancker D. L.; LANS, Ivo A. Van der; MIDDEN, Cees J. H. Cognitive structures in the perception of modern technologies. Science, Technology \& Human Values, v. 5, n. 2, p.202-225. 1990. Disponível em: < http://goo.gl/aCkHTU>. Acesso em: 09 jun. 2015. ISSN 1552-8251.

DAHINDEN, Urs. Biotechnology: From inter-science to international controversies. Public Understanding of Science, v. 11, n. 2, p. 87-92. 2002. Disponível em: 〈http://goo.gl/Bi5RyX $\rangle$. Acesso em: 09 jun. 2015. ISSN 1361-6609.

ENEMARK, Stig. Innovation in Surveying education. Global Journal of Engineering Education, Melbourne, v. 06, n. 02, p. 153-160. 2002. Disponível em: < http://goo.gl/sZV0ih>. Acesso em: 09 jun. 2015. ISSN 1933-1703.

FISHER, Mark; SMALL, Bruce; ROTH, Hein; MALLON, Mary; JEREBINE, Bryce. What do individuals in different science groups within a life sciences organization think about genetic modification? Public Understanding of Science, v. 14, n. 3, p. 317-326. 2005. Disponível em: < http://goo.gl/WqvLk2>. Acesso em: 09 jun. 2015. ISSN 1361-6609.

GARCÍA, M. I. G. et. al. Ciencia tecnología y sociedad: Una introducción al estudio social de la ciencia y la tecnología. Espanha: Tecnos, 2000.

GARDNER, Paul Leonard. The dimensionality of attitude scales: a widely misunderstood idea. International Journal of Science Education, v. 18, p. 913-919. 1996. Disponível em: < http://goo.gl/3iN9QH >. Acesso em: 09 jun. 2015. ISSN 1464-5289.

GIL PÉREZ, Daniel; MONTORO, Isabel Fernández; ALÍS, Jaime Carrascosa; CACHAPUZ, António; PRAIA, João. Para uma imagem não deformada do trabalho científico. Ciência \& Educação, Bauru, SP, v. 07, n. 02, p. 125-153. 2001. Disponível em: < http://goo.gl/340YLE>. Acesso em: 09 jun. 2015. ISSN 1980-850X.

GODIN, Benoit; GINGRAS, Yves. What is scientific and technological culture and how is it measured? A multidimensional model. Public Understanding of Science, v. 09, n. 01, p. 43-58. 2000. Disponível em: < http://goo.gl/qaCvl2 >. Acesso em: 09 jun. 2015. ISSN 1361-6609.

GÓMEZ, S. Cáceres. Los estudios Ciencia, Tecnología y Sociedad y la Educación para el Desarrollo. Ingenieria Sin Fronteras - Revista de Cooperación, Madrid, ES, v. 1, n. 14, p. 1-5. 2001. Disponível em: < http://goo.gl/a2U2MK>. Acesso em: 09 jun. 2015.

GOSLING, Marlusa; GONÇALVES, Carlos Alberto. Modelagem de Equações Estruturais: Conceitos e Aplicações. FACES - Revista de Administração, Belo Horizonte, MG, v. 02, n. 02, p. 83-95. 2003. Disponível em: < http://goo.gl/nuatbq>. Acesso em: 09 jun. 2015. ISSN 1984-6975.

GUIVANT, Julia S. Transgênicos e percepção pública da ciência no Brasil. Ambiente \& Sociedade, São Paulo, SP, v. 09, n. 01. 2006. Disponível em: 〈http://goo.gl/7nXcbZ>. Acesso em: 25 jul. 2009. ISSN 1809-4422.

HAIR-JUNIOR, Joseph; BLACK, William C.; BABIN, Barry J.; ANDERSON, Rolph E.; TATHAM, Ronald L. Análise multivariada de dados. Porto Alegre: Bookman, 2005.

HORST, Maja. Cloning sensations: mass mediated articulation of social responses to controverial biotechnology. Public Understanding of Science, v. 9, n. 4, p. 185-200. 2000. Disponível em: < http://goo.gl/7FKkI2>. Acesso em: 09 jun. 2015. ISSN 1361-6609. 
KAMALDEEN, S.; BLAINE, K; POWELL, D. Public perceptions of biotechnology. Journal of Food Science, v. 67, n. 09. 2002. Disponível em: < http://goo.gl/7FKkI2>. Acesso em: 09 jun. 2015. ISSN 1750-3841.

KERR, Anne, CUNNINGHAM-BURLEY, Sarah; TUTTON, Richard. Shifting subject positions: experts and lay people in public dialogue. Social Studies of Science, v. 37, n. 03, p. 385-411. 2007. Disponível em: < http://goo.gl/2EYHeD>. Acesso em: 09 jun. 2015. ISSN 1460-3659.

LEDERMAN, Norman G.; O'MALLEY, Molly. Students' perceptions of tentativeness in science: development, use, and sources of change. Science Education, v. 74, n. 02, p. 225-239. 1990. Disponível em: 〈http://goo.gl/gBZHLI $>$. Acesso em: 09 jun. 2015. ISSN 1098-237X.

LATOUR, Bruno; WOOLGAR, Steve. A vida de laboratório: a produção dos fatos científicos. Rio de Janeiro: Relume Dumará, 1997.

LIAKOPOULOS, Miltos. Pandora's box or panacea? Using metaphors to create the public representations of biotechnology. Public Understanding of Science, v. 11, n. 1, p. 5-32. 2002. Disponível em: < http://goo.gl/duVWUs >. Acesso em: 09 jun. 2015. ISSN 1361-6609.

MACDONALD, Donald. Conceptualizing some unique features of the teaching os science. ASEJ. v. 29, n. 2. 1996.

MALHOTRA, Naresh K. Pesquisa de marketing: uma orientação aplicada. 3. ed. Porto Alegre: Bookman, 2001.

MAS, María Antonia Manassero; ALONSO, Ángel Vázquez; DÍAZ, José Antonio Acevedo. La evaluación de las actitudes CTS. Enseñanza de las Ciencias, v. 22, p. 299-312. 2004. Disponível em: <http://goo.gl/EnvZx3 >. Acesso em: 09 jun. 2015. ISSN 1681-5645.

MASSARANI, Luisa; MOREIRA, Ildeu de Castro. Attitudes toward genetics: a case study among Brazilian high school students. Public Understanding of Science, v. 14, n. 2, p. 201-212. 2005. Disponível em: < http://goo.gl/KsMw9t>. Acesso em: 09 jun. 2015. ISSN 1361-6609.

MERTON, Robert King. Os imperativos institucionais da ciência. In: Merton, Robert King; DEUS, Jorge Dias de. A crítica da ciência: sociologia e ideologia da ciência. Rio de Janeiro: Zahar, 1979.

MERTON, Robert King. La sociologia de la ciencia, investigaciones teóricas y empíricas. Mardi: Alianza Editorial, p. 339-354, 1977.

MINAYO, Maria Cecília de Souza (Org.). Pesquisa social: teoria, método e criatividade. Rio de Janeiro: Vozes, 2001.

OLASEHINDE, Kayode John.; OLATOYE, Rafiu Ademola. Scientific attitude, attitude to science and science achievement of senior secondary school students in Katsina State, Nigeria. Journal of Educational and Social Research, v. 04, n. 01, p. 445-542. jan./2014. Disponível em: < http://goo.gl/ww7eXL>. Acesso em: 09 jun. 2015. ISSN 2240-0524.

PASQUALI, Luiz. Psicometria: teoria dos testes na Psicologia e na Educação. Petrópolis: Vozes, 2003.

PATTON, Michael Quinn. Qualitative evaluation and research methods. Sage Publications. Second Edition. Newburry Park, California, USA, 1980. 
PITRELLI, Nico; MANZOLI, Federica; MONTOLLI, Barbara. Science in advertising: uses and consumptions in the Italian press. Public Understanding of Science, v. 15, n. 2, p. 207-220. 2006. Disponível em: < http://goo.gl/zvs7im>. Acesso em: 09 jun. 2015. ISSN 1361-6609.

SANDERSON, Saskia. C.; WARDLE, Jane; MICHIE, Susan. The effects of a genetic information leaflet on public attitudes toward genetic testing. Public Understanding of Science, v. 14, n. 2, p. 213-224. 2005. Disponível em: < http://goo.gl/Lx8BdF>. Acesso em: 09 jun. 2015. ISSN 1361-6609.

SELLTIZ, C.; WRIGHTSMAN, L.S.; COOK, S. Métodos de pesquisa nas relações sociais. 2. ed. São Paulo: EPU, 1987.

SHRIGLEY, Robert L; KOBALLA-JUNIOR, Thomas R. A decade of attitude research based on Hovland's learning model. Science Education, v. 76, n. 01, p. 17 - 42. 1992. Disponível em: < http://goo.gl/AHBv0N>. Acesso em: 09 jun. 2015. ISSN 1098-237X.

SIMON, Fernanda Oliveira. Percepção de Ciência: relações entre conhecimentos, crenças, atitudes e fatores sócio-demográficos. 2009. 201 f. Tese (Doutorado em Educação) - Faculdade de Educação, Universidade Estadual de Campinas, Campinas, SP, 2009. Disponível em: < http://goo.gl/pulXoA $>$. Acesso em: 09 jun. 2015.

SIMPSON, Ronald D.; WASIK, John L. Correlation of selected affective behaviours with cognitive performance in a biology course for elementary teachers. Journal of Research in Science Teaching, v. 15, n. 1, p. 65- 71. 1978. Disponível em: < http://goo.gl/tM1pZy>. Acesso em: 09 jun. 2015. ISSN 10982736 .

SLEE, F. W. A factorial study of the study attributes of secondary modern children to school subjects. Anthropologist, v. 10 n. 1, p. 21-24. 1964.

SOYIBO, K. A. Comparison of selected lagos students attitude to performance on a biology test. Anthropologist, v. 10 n. 1, p. 21-24, 1985.

TYTLER, Russell; DUGGAN, Sandra; GOTT, Richard. Public participation in environmental dispute: implications for science education. Public Understanding of Science, v. 10, n. 4, p. 343-364. 2001. Disponível em: < http://goo.gl/N90CNP>. Acesso em: 09 jun. 2015. ISSN 1361-6609.

VERASZTO, Estéfano Vizconde; SILVA, Dirceu da; CAMARGO, Eder Pires de; BARROS-FILHO, Jomar. Concepções de tecnologia de graduandos do estado de São Paulo e suas implicações educacionais: breve análise a partir de modelagem de equações estruturais. Ciência \& Educação, Bauru, SP, v. 19, p. 761-779. 2013. Disponível em: < http://goo.gl/8svMla >. Acesso em: 09 jun. 2015. ISSN 1980-850X.

VERASZTO, Estéfano Vizconde; CAMARGO, José Tarcísio Franco de; SILVA, Dirceu da; FREITAS, Leandro Valim de. Technology and society public perception: a structural equation modeling study of the brazilian undergraduate students opinions and attitudes from Sao Paulo state. In: FREITAS, Leandro Valim de; FREITAS, Ana Paula Barbosa Rodrigues de (Org.). Multivariate analysis in Manaigement, Engineering and the Sciences. Rijeka, Croacia: InTech Europa, 2012, v.1, p.3-14. Disponível em: < http://goo.gl/HNi8xi>. Acesso em: 09 jun. 2015.

VERASZTO, Estéfano Vizconde, BARROS-FILHO, Jomar; SILVA, Dirceu da. Educación, tecnología y sociedad: relaciones de causalidad de la influencia social en los procesos de toma de decisiones tecnológicas. ETD - Educação Temática Digital, Campinas, SP, v. 12, p. 126-153. 2011. Disponível em: 〈http://goo.gl/pWSLXx $>$. Acesso em: 09 jun. 2015. ISSN 1676-2592. 
VILLANI, Alberto. Filosofia da Ciência e ensino de Ciência: Uma analogia. Ciência \& Educação, Bauru, SP, v. 07, n. 02, p. 169-181. 2001. Disponível em: 〈 http://goo.gl/wPYBPb>. Acesso em: 09 jun. 2015. ISSN 1516-7313.

VOGT, Carlos; POLINO, C. Percepção pública da Ciência: resultado da pesquisa na Argentina, Brasil, Espanha e Uruguai. Campinas: Editora da Unicamp, São Paulo: Fapesp, 2003.

WILSON, Victor L. A meta analysis of the relationship between science and achievement and science attitude kindergarten through college. Journal of Research in Science Teaching, v. 20, n. 09, p. 839855. 1983. Disponível em: < http://goo.gl/T4OzzT>. Acesso em: 09 jun. 2015. ISSN 1098-2736.

\section{Como citar este documento:}

SIMON, Fernanda Oliveira Simon et al. Public perception of science of undergraduate students from the state of São Paulo: a study through the perspective of biotechnology. ETD - Educação Temática Digital, Campinas, SP, v. 18, n. 1, p. 83-103, abr. 2016. ISSN 1676-2592. Disponível em:

<http://periodicos.sbu.unicamp.br/ojs/index.php/etd/article/view/8635752>. Acesso em: 05 abr. 2016. doi: 〈http://dx.doi.org/10.20396/etd.v18i1.8635752>. 